\title{
KAJIAN TEORITIS KEMAMPUAN CAPPING KATEKIN, KATEKU TANAT DAN QUARSETIN TERHADAP NANOPARTIKEL PERAK DENGAN MENGGUNAKAN METODA DFT-B
}

\author{
Syukri Arief, Emriadi, dan Harry Ade Saputra \\ Jurusan Kimia, Universitas Andalas, Padang, 25163, Indonesia \\ Email: syukriarief@gmail.com
}

\begin{abstract}
Interdiffusion mechanism of catechin, catechutannic acid and quercetin are studied by using DFT-B method. But before conducting these experiment, we perform molecular dynamic simulations to find adsorption models probability of each compound. Two models adsorption of quarcetin, four models for catechin and three models for catechutannic acid have been obtained from molecular dynamic simulations. Quantum parameter of each compound, energy and properties adsorption models have been calculated and discussed. The theoretical results were found to be consistent with the experimental data reported. Futhermore, optimization adsorption model samples show that all of adsorbents have weak bonds on the surface of silver nanoparticles. The mechanism can be classified as strong physisorption, so that catechin, catechutannic acid and quercetin can be categorized as good capping agent in synthesis of silver nanoparticles.
\end{abstract}

Keywords: Silver Nanoparticle, Capping, Adsorption, DFTB

\section{PENDAHULUAN}

Nanoteknologi adalah teknik atau metoda yang digunakan untuk mengontrol bentuk dan struktur suatu bahan pada skala atom, agar diperoleh material dengan sifat lebih unggul dan lebih baik ${ }^{[1]}$. Nanoteknologi mengalami perkembangan yang sangat pesat pada satu dekade terakhir. Terbukti dengan pertumbuhan jumlah produk nanoteknologi dipasaran, yang telah mencapai 1814 jenis produk yang tersedia dipasaran hingga tahun 2014. Nanopartikel perak merupakan salah satu material nano yang paling banyak digunakan, dimana hampir seperlima produk nanoteknologi yang beredar dipasaran mengandung material perak ${ }^{[2]}$.

Berbagai metoda dikembangkan untuk menghasilkan nanopartikel perak, dan salah satu metoda sintesis nano partikel perak yang berkembang saat ini adalah metoda reduksi menggunakan ekstrak tumbuhan. Berbagai macam ekstrak tumbuhan terbukti mampu menghasilkan nanopartikel perak dengan dengan ukuran partikel yang halus, seperti : ekstrak Citrullus colocynthis ${ }^{[3]}$, Camellia sinensis ${ }^{[4]}$, Dioscorea bulbifera ${ }^{[5]}$, Rumex hymenosepalus ${ }^{[6]}$ dan Withania somnifera ${ }^{[7]}$. Kemampuan ekstrak tumbuhan yang dapat bertindak sebagai reduktor sekaligus capping agent pada proses sintesis nanopartikel, tidak terlepas dari kandungan senyawa metabolit sekunder, seperti fenolik, tanin dan saponin yang ada didalam ekstrak tumbuhan tersebut ${ }^{[8]}$.

Capping adalah proses adsorpsi senyawa organik, yang memiliki sifat hidrofobik dan efek steric hindrance pada permukaan partikel, yang dapat mencegah terjadinya proses aglomerasi ${ }^{[9]}$. Proses capping merupakan salah satu tahapan utama pada proses sintesis nanopartikel perak, sehingga menpelajari proses adsorpsi capping agent 
pada permukaan logam, merupakan hal yang menarik dan penting untuk dipelajari.

Mekanisme interdifusi adsorbat pada permukaan substrat dalam proses adsorbsi, sudah banyak dipelajari baik secara eksperimen maupun secara teoritis. Secara teoritis dalam bidang komputasi, metoda yang cukup sering digunakan untuk mempelajari mekanisme interdifusi adsorbsi adalah metoda DFT-B (Density Functional Tight Binding) ${ }^{[10]}$. DFT-B adalah metoda semi-empirik yang merupakan penurunan persamaan DFT-GGA, sehingga untuk sistem tertentu metoda ini memiliki akurasi perhitungan yang baik sama halnya dengan metoda DFT itu sendiri [11]. Metoda ini berkembang sangat pesat dan banyak digunakan dalam mempelajari sifat-sifat dari suatu sistem. Beberapa penelitian seperti adsorpsi asam asetat pada permukaan titania $^{[12]}$, air pada permukaan $\mathrm{ZnO}{ }^{[13]}$ dan Asam karboksilat pada permukaan $\mathrm{TiO}_{2}$ berhasil dibuktikan secara teoritis menggunakan metoda DFT-B ${ }^{[14]}$.

\section{METODOLOGI PENELITIAN}

Sebelum penelitian dilaksanakan, terlebih dahulu dilakukan simulasi dinamika molekular untuk tiap-tiap senyawa yang digunakan, sehingga didapatkan perkiraan model-model adsorbsi senyawa pada permukaan kristal perak. Dari hasil simulasi dinamika molekular didapatkan dua model penjatuhan quarsetin, empat model penjatuhan katekin dan tiga model penjatuhan kateku tanat, yang selanjutnya akan dioptimasi menggunakan metoda DFTB.

Perhitungan komputasi dilakukan menggunakan kode Density Functional Tight Binding Plus (DFTB +$)^{[15]}$ dan Selfconsistent Charge Density Functional Tight Binding (SCC-DFTB) ${ }^{[16]}$. Penelitian ini menggunakan parameter set (Slater-Koster files) "hyb" yang merupakan parameter SCC files organik dan anorganik hibrid sistem, terutama untuk mempelajari adsorpsi senyawa organik pada permukaan perak, GaAs dan silicon ${ }^{[17]}$. (a)

(b)
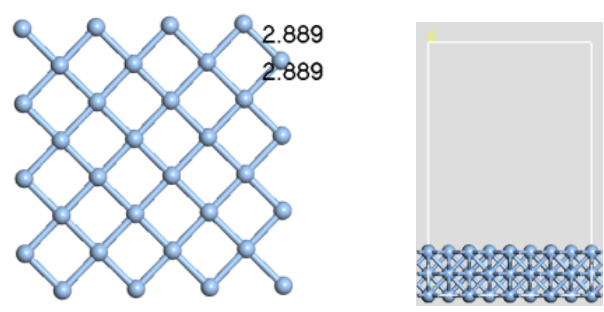

Gambar 1. (a) permukaan kristal perak, (b) sistem ikatan berkala kristal perak.

Perhitungan dilakukan dalam sistem ikatan berkala permukaan perak (100) dengan ukuran kisi axbxc $(16,3412$ x 24 x 16,3412 A) dan jumlah atom perak sebanyak 96 atom pada sistem 3 lapis, seperti yang terlihat pada Gambar 1a dan 1b, yang bertujuan agar permukaan perak cukup luas untuk menampung adsorbat saat dilakukan proses adsorbsi. Gambar 2, 3 dan 4 merupakan sistem yang dipelajari pada penelitian ini yaitu empat bentuk kemungkinan adsorbsi katekin pada permukaan perak, tiga bentuk kemungkinan adsorbsi kateku tanat dan dua bentuk kemungkinan adsorbsi quarsetin pada permukaan perak yang telah diperoleh melalui simulasi dinamika molekular. Seluruh struktur dioptimasi menggunakan metoda DFTB, dimana seluruh atom-atom perak dibuat kaku, sehingga tidak terjadi relaksasi pada atom-atom perak saat optimasi geometri dilakukan.

(a)

(b)

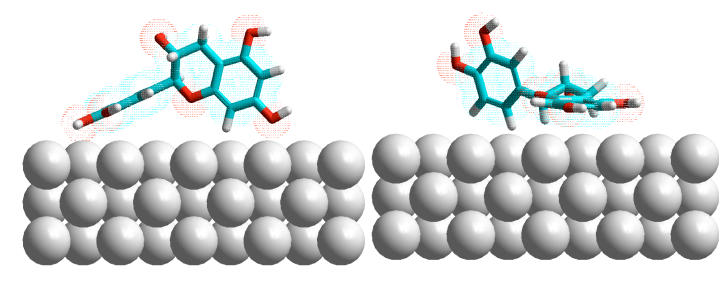

(c)

(d)

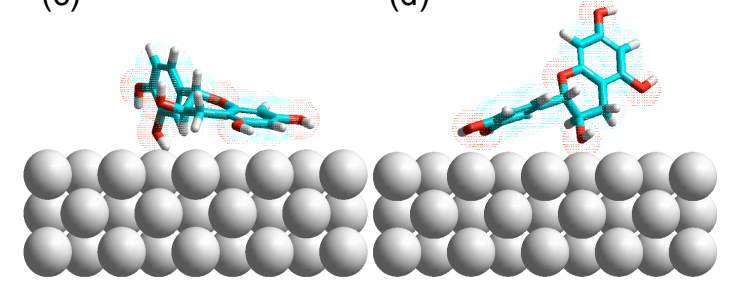

Gambar 2. Kemungkinan penjatuhan katekin (a) katekin-1, (b) katekin-2, (c) katekin-3, (d) katekin-4. 
(a)
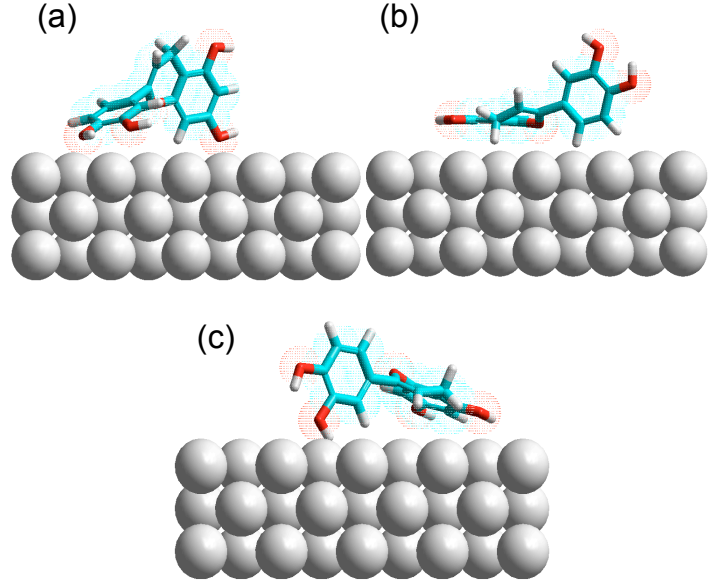

Gambar 3. Kemungkinan penjatuhan kateku tanat (a) kateku tanat-1, (b) kateku tanat-2, (c) kateku tanat-3.

(a)

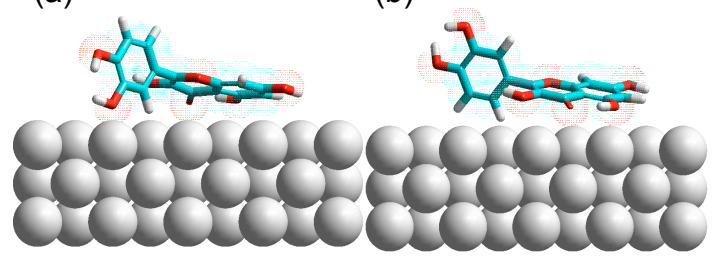

Gambar 4. Kemungkinan penjatuhan quarsetin (a) quarsetin-1, (b) quarsetin-2.

Sistem ini dibuat dengan asumsi bahwa adsorbat teradsorbsi pada permukaan kristal perak sempurna. Sementara Seluruh atomatom penyusun katekin, kateku tanat dan quarsetin dibiarkan bergerak saat proses optimasi geometri berlangsung.

Untuk menciptakan kondisi yang riil dari sistem, grid k-vektor di atur pada sistem, dengan penggandaan grid k-point dua ke arah sumbu $\mathrm{x}$ dan sumbu $\mathrm{y}$, dan satu ke arah sumbu z. SCC toleransi 0,01 dengan skema pencampuran metoda "broyden $(0,2)$ " dan eigensolver "devide and conquer". Konvergen toleransi di atur $0,005 \mathrm{eV}$ dan smearing $0,01 \mathrm{Ha}$.

Energi ikatan adsorpsi satu molekul katekin, kateku tanat dan quarsetin didapatkan dengan menghitung selisih energi kombinasi sistem dan energi sistem yang terisolasi.

$$
\Delta \mathrm{E}_{\mathrm{ikt}}=\Delta \mathrm{E}_{\text {sub+abs }}-\Delta \mathrm{E}_{\text {sub }}-\Delta \mathrm{E}_{\text {abs }}
$$

dimana $\mathrm{E}_{\text {sub+abs }}$ adalah energi optimasi sistem adsorbat yang teradsorbsi pada permukaan perak, $E_{\text {sub }}$ dan $E_{\text {abs }}$ merupakan energi masing-masing substrat dan adsorbat pada sistem terisolasi. Untuk menghitung energi adsorbat dan substrat terisolasi, sistem komputasi dibuat sama yaitu dalam sistem ikatan berkala dan sistem perhitungan yang sama.

\section{HASIL DAN DISKUSI}

Struktur kimia katekin, kateku tanat dan quarsetin ditunjukan pada Gambar 5. Dari Gambar 5 tersebut dapat dilihat, senyawasenyawa ini memiliki gugus-gugus hidroksi kaya elektron bebas, yang dapat disumbangkan untuk membentuk ikatan dengan persenyawaan elektropositif seperti kristal perak ${ }^{[18]}$.

Kereaktifan dari senyawa-senyawa polifenol yang digunakan sebagai capping agent, sangat dipengaruhi oleh jumlah gugus hidroksi yang ada pada molekul-molekul tersebut ${ }^{[19,20]}$. Akan tetapi pada proses adsorpsi, efek sterik dan model penjatuhan diperkirakan juga akan berpengaruh cukup besar terhadap energi adsorpsi dari molekulmolekul tersebut.<smiles>Oc1cc(O)c2c(c1)OC(c1ccc(O)c(O)c1)[C@H](O)C2</smiles><smiles>Oc1cc(O)c2c(c1)OC(c1ccc(O)c(O)c1)=CC2</smiles><smiles>O=c1c(O)c(-c2ccc(O)c(O)c2)oc2cc(O)cc(O)c12</smiles>

Gambar 5. Struktur molekul (a) katekin, (b) kateku tanat (c) quarsetin.

Tabel 1 merupakan hasil optimasi katekin, kateku tanat dan quarsetin pada sistem terisolasi menggunakan metoda DFT-B, DFT 
dan PM3. Hasil optimasi tersebut memperlihatkan molekul quarsetin memiliki kereaktifan yang lebih tinggi dibandingkan dengan katekin karena memiliki energi gap yang lebih kecil. Data ini sesuai dengan data eksperimen yang menunjukan bahwa keberadaan gugus hidroksi dan karbonil pada suatu senyawa polifenol, akan meningkatkan kereaktifan senyawa tersebut ${ }^{[23,24]}$. Selain itu data ini juga membuktikan bahwa pada sistem tertentu, terutama sistem yang dipelajari saat ini, metoda DFT-B memiliki akurasi perhitungan yang sama baiknya dengan menggunakan metoda DFT itu sendiri.

Hasil optimasi model-model penjatuhan katekin, kateku tanat dan quarsetin menggunakan metoda DFT-B selanjutnya dibandingkan dengan hasil eksperimen sintesis nanopartikel emas menggunakan katekin dan quarsetin, serta persen enkapsulasi senyawa tersebut pada permukaan nanopartikel emas, yang memiliki sifat hampir sama dengan nanopartikel perak $^{[25]}$ seperti yang terlihat pada Tabel 2. Dari Tabel 2 dapat dilihat quarsetin memiliki energi adsorpsi rata-rata yang lebih besar dibandingkan dengan katekin. Dengan energi adsorbsi sebesar 29,93 $\mathrm{kkal} / \mathrm{mol}$, menyebabkan quarsetin dapat terserap lebih banyak pada permukaan perak yaitu sebesar $79,84 \%$, dibandingkan katekin yang hanya terserap sebesar $76,14 \%$ karena memiliki energi adsorbsi lebih kecil yaitu sebesar $20,37 \mathrm{kkal} / \mathrm{mol}$.
Dari data eksperimen pada Tabel 2 juga memperlihatkan ukuran nanopartikel hasil sintesis nanopartikel emas menggunakan senyawa quarsetin yaitu sebesar $399,67 \mathrm{~nm}$, lebih kecil dibandingkan dengan ukuran nanopartikel emas yang disintesis menggunakan senyawa katekin, yakni sebesar 410,59 nm. Hasil ini sesuai dengan teori bahwa semakin kuat adsorbat teradsorbsi pada permukaan substrat, maka akan semakin kuat untuk menghalangi proses aglomerasi partikel, sehingga nanopartikel yang dihasilkan akan semakin kecil ${ }^{[27]}$.

Range persen enkapsulasi katekin pada Tabel 2 memiliki nilai sebesar $\pm 6,13 \%$, angka ini lebih besar jika dibandingkan dengan range persen enkapsulasi quarsetin yaitu sebesar $\pm 2,5 \%$. Data ini diperkirakan berkaitan dengan kemungkinan variasi model penjatuhan adsorbat pada permukaan substrat. Semakin sedikit variasi model penjatuhan adsorbat pada permukaan substrat diperkirakan akan menurunkan persen range enkapsulasi senyawa pada permukaan logam, dengan kata lain akan meningkatkan kehomogenan ukuran nanopartikel hasil sintesis menggunakan senyawa tersebut dan begitu juga sebaliknya.

Energi ikatan antara katekin, kateku tanat dan quarsetin kurang dari $100 \mathrm{kkal} / \mathrm{mol}$, diperkuat dengan panjang ikatan antara katekin, kateku tanat dan quarsetin dengan permukaan perak bernilai lebih dari 2,0 А̃ seperti yang terlihat pada Gambar 6, yang menunjukan molekul katekin, kateku tanat dan quarsetin hanya teradsorpsi secara fisika ${ }^{[28]}$.

Tabel 1. Merupakan hasil optimasi DFTB katekin, kateku tanat dan quarsetin pada sistem terisolasi, yang dibandingkan dengan hasil optimasi DFT dan PM3

\begin{tabular}{lccc}
\hline \multicolumn{1}{c}{ Energi $(\mathrm{eV})$} & DFT-B & $\begin{array}{c}\text { DFT } \\
(\text { CASTEP) }\end{array}$ & $\begin{array}{c}\text { PM3 } \\
\left(\text { MOPAC) }{ }^{[22]}\right.\end{array}$ \\
\hline Quarsetin $\mathrm{E}_{\text {HOMO }}$ & $-5,326$ & $-5,472$ & $-9,027$ \\
Quarsetin $\mathrm{E}_{\text {LUMO }}$ & $-2,083$ & $-1,799$ & $-1,484$ \\
Quarsetin $\mathrm{E}_{\text {gap }}$ & 3,243 & 3,672 & 7,543 \\
Katekin $\mathrm{E}_{\mathrm{HOMO}}$ & $-5,373$ & $-5,566$ & $-8,846$ \\
Katekin $\mathrm{E}_{\mathrm{LUMO}}$ & $-1,248$ & $-0,167$ & $-0,205$ \\
Katekin $\mathrm{E}_{\text {gap }}$ & 4,125 & 5,733 & 8,641 \\
Kateku tanat $\mathrm{E}_{\text {HOMO }}$ & $-5,199$ & - & - \\
Kateku tanat $\mathrm{E}_{\text {LUMO }}$ & $-1,421$ & - & - \\
Kateku tanat $\mathrm{E}_{\text {gap }}$ & 3,778 & - & - \\
\hline
\end{tabular}


Tabel 2. Energi adsorpsi hasil optimasi model-model penjatuhan katekin, kateku tanat dan quarsetin pada permukaan perak, yang dibandingkan dengan persen enkapsulasi dan ukuran partikel emas hasil eksperimen

\begin{tabular}{lllll}
\hline \multirow{2}{*}{ Model adsorpsi } & Energi ikatan $(\mathrm{kkal} / \mathrm{mol})$ & $\begin{array}{l}\text { Enkapsulasi } \\
\text { PLGA (\%) }\end{array}$ & $\begin{array}{l}\text { Ukuran Partikel } \\
\text { PLGA (nm) }{ }^{[26]}\end{array}$ \\
\cline { 3 - 4 } & & Rata-rata & & $\mathbf{7 9 , 8 4}$ \\
Quarsetin 01 & $-34,8934$ & $\mathbf{- 2 9 , 9 2 9 9}$ & $\mathbf{3 9 9 , 6 7}$ \\
Quarsetin 02 & $-24,9663$ & 2 model & $\pm 2,5$ & \\
\hline Katekin 01 & $-18,0271$ & & & \\
Katekin 02 & $-25,7087$ & $\mathbf{- 2 0 , 3 7 3 4}$ & $\mathbf{7 6 , 1 4}$ & $\mathbf{4 1 0 , 5 9}$ \\
Katekin 03 & $-16,5436$ & 4 model & $\pm 6,13$ & \\
Katekin 04 & $-21,2143$ & & & \\
\hline Kateku tanat 01 & $-30,6298$ & & & - \\
Kateku tanat 02 & $-24,9748$ & - & - & \\
Kateku tanat 03 & $-16,5758$ & & & \\
\hline
\end{tabular}

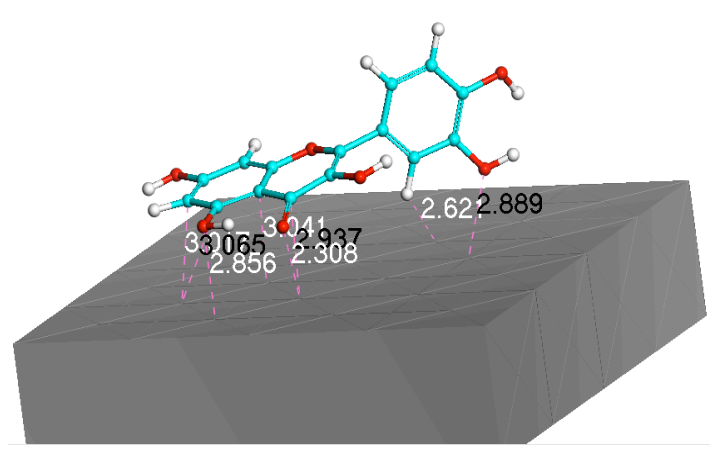

Gambar 6. Panjang rata-rata ikatan molekul katekin, kateku tanat dan quarsetin pada permukaan perak bernilai lebih dari 2,0 $\tilde{A}$.

Adsorpsi secara fisik yang terjadi antara katekin, kateku tanat dan quarsetin membuat molekul-molekul tersebut dapat menghasilkan nanopartikel dengan ukuran yang baik tanpa merusak struktur kristal tersebut dan juga membuat senyawa ini lebih mudah dipisah dari produk nanopartikel yang dihasilkan ${ }^{[29]}$.

\section{KESIMPULAN}

Dari hasil perhitungan yang didapatkan, metoda DFT-B memiliki akurasi yang sama baiknya dengan perhitungan komputasi menggunakan metoda DFT dalam mempelajari mekanisme interdifusi senyawa organik pada permukaan perak. Hasil perhitungan DFT-B memperlihatkan senyawa katekin, kateku tanat dan quarsetin merupakan senyawa capping agent yang baik, akan tetapi diantara ketiga senyawa tersebut, quarsetin merupakan capping agent yang paling baik digunakan untuk menghasilkan nanopartikel dengan ukuran dan tingkat kehomogenan yang baik.

\section{DAFTAR PUSTAKA}

1. Karkare, M. Nanotechnology: Fundamentals and Applications. LK. International Publishing House Pvt. Ltd, New Delhi. 21-50 (2008).

2. Vance, M. E., Kuiken, T., Vejerano, E. P., McGinnis, S. P., Hochella Jr, M. F., Rejeski, D., \& Hull, M. S., Nanotechnology in the real world: Redeveloping the nanomaterial 
consumer products inventory. Beilstein J. Nanotechnol., 6: 1769-1780 (2015).

3. Satyavani, K., Gurudeeban, S., Ramanathan, T., \& Balasubramanian, T. Biomedical potential of silver nanoparticles synthesized from calli cells of Citrullus colocynthis (L.) Schrad, J. Nanotechnol., 9(43): 1-8 (2011).

4. Loo, Y. Y., Chieng, B. W., Nishibuchi, M., \& Radu, S. Synthesis of silver nanoparticles by using tea leaf extract from Camellia Sinensis, Int. J. Nanomedicine, 7: 4263-4267 (2012).

5. Chopade, B., Ghosh, S., Patil, S., Synthesis of silver nanoparticles using Dioscorea bulbifera tuber extract and evaluation if its synergistic potential in combination with antimicrobial Agents, Int. J. Nanomedicine, 7: 483-496. (2012).

6. Leon, R. et al., Synthesis of silver nanoparticles using reducing agents obtained from natural sources (Rumex Hymenosepalus Extracts), Nanoscale Res. Lett., 8(318): 1-8 (2013).

7. Marslin, G. et al. Antimicrobial activity of cream incorporated with silver nanoparticles biosynthesized from Withania somnifera, Int. J. Nanomedicine, 10: 5955-5963 (2015).

8. Kulkarni, N. dan Muddapur, U. Biosynthesis of Metal Nanoparticles: A Review, J. Nanotechnol., 1-8 (2014).

9. Daimon, H. Progress in Cathode Catalysts for PEFC: Advance Materials for Clean Energy, (Ed: Q. Xu dan T. Kobayashi) CRC press LLC, Florida. Bab 17, pp 549-559. (2015).

10. Oliveira, A.F., Seifert, G., Heine, T. and Duarte, H.A., Density-Functional Based Tight-Binding: an Approximate DFT Method. J. Braz. Chem. Soc., 20(7): 1193-1205 (2009).

11. Elstner, M. dan Seifert G. Density Functional Tight Binding. Royal Society, Phil. Trans., 1-9, (2016).

12. Manzhos, S., Giorgi, G. dan Koichi Yamashita, K. A Density functional tight binding study of acetic acid adsorption on crystalline and amorphous surfaces of titania. Molecules, 20: 33713388 (2015).

13. Hellström, M., Jorner, K., Bryngelsson, M., Huber, S.E., Kullgren, J., Frauenheim, T. dan Broqvist, P., An
SCC-DFTB repulsive potential for various $\mathrm{ZnO}$ polymorphs and the ZnO-Water system. J. Phys. Chem. C, 117: 17004-17015 (2013).

14. Heckel, W., Elsner, B.A., Schulz, C. dan Müller, S., The role of hydrogen on the adsorption behavior of carboxylic acid on $\mathrm{TiO}_{2}$ surfaces, $J$. Phys. Chem. C, 118(20): 10771-10779 (2014).

15. Aradi, B., Hourahine, B. dan Frauenheim, T., DFTB + , a sparse matrix-based implementation of the DFTB method, J. Phys. Chem. A, 111(26): 5678 (2007).

16. Elstner, M., Porezag, D., Jungnickel, G., Elsner, J., Haugk, M., Frauenheim, T., Suhai, S. dan Seifert, G., Selfconsistent-charge density-functional tight-binding method for simulations of complex materials properties. Phys. Rev. $B, \mathbf{5 8 : 7 2 6 0 ~ ( 1 9 9 8 ) . ~}$

17. Szucs, B., Hajnal, Z., Scholz, R., Sanna, S. dan Frauenheim, T., Theoretical study of the adsorption of a PTCDA monolayer on S-passivated GaAs (100), Appl. Surf. Sci., 234: 173. (2004).

18. Housecroft, C. E. dan Sharpe, A. G. Inorganic Chemistry $2^{\text {nd }}$ Edition. Pearson Education Ltd, Essex. 162-188 (2004).

19. Majumdar, R., Gopal, B. dan Maity, N. Acacia nilotica (Babool) leaf extract mediated size-controlled rapid synthesis of gold nanoparticles and study of its catalytic activity. Int. Nano Lett., 3: 53 (2013).

20. Ebrahiminezhad A. et al. Biomimetic synthesis of silver nanoparticles using microalgal secretory carbohydrates as a novel anticancer and antimicrobial. $A d v$. Nat. Sci.: Nanosci. Nanotechnol. 7: 1-8 (2016).

21. Nnaji, N. J. N., Obi-Egbedi, N. O. dan Okoye, C. O. B. Cashew nut testa tannin: assessing its effects on the corrosion of aluminium in $\mathrm{HCl}$. Port. Electrochim. Acta, 32: 157-182 (2014).

22. Kavitha, V. dan Gunavathy, N. Quantum chemical studies on efficiencies of catechin, epicatechin gallate, epigallocatechin and quercetinas corrosion inhibitors, PSGCAS Search: $A$ Journal of Science and Technology, 2 (2): 7-11 (2015). 
23. Abraham, T. E. dan Zakaria, Z. A. Reactivity of phenolic compounds towards free radicals under in vitro conditions., J. Food Sci. Technol. 52: 5790 (2015).

24. Michalak, A. Phenolic compounds and their antioxidant activity in plants growing under heavy metal stress. Polish J. Environ. Stud., 15(4): 523-530 (2006).

25. Housecroft, C. E. dan Sharpe, A. G. Inorganic Chemistry $2^{\text {nd }}$ Edition. Pearson Education Ltd, Essex. 689-694 (2004).

26. Pool, H. et al., Antioxidant effects of quercetin and catechin encapsulated into
PLGA nanoparticles, J. Nanomater., 111 (2012).

27. Israelsen, N. D., Hanson, C. dan Vargis, E., Nanoparticle properties and synthesis effects on surface-enhanced Raman scattering enhancement factor: An Introduction. Hindawi Publishing, The Scientific World Journal, 1-12 (2015).

28. Noll, K. E., Gounaris, V., dan Hou, W. Adsorption technology for air and water pollution control. Lewis Publishers, Chelsea, Mich. 21-49 (1992).

29. Duan, H., Wang, D. dan Li, Y. Green chemistry for nanoparticle synthesis. Chem. Soc. Rev., 44: 5778-5792 (2015). 